\title{
HAVAINTOJA MUUTAMIEN NURMIKASVIEN KEHITYKSESTÄ KYLVÖKESÄN AIKANA.
}

\author{
Martti Salonen \\ Helsingin Yliopiston Kasvinviljelystieteen laitos.
}

Saapunut 5. 4. 1951.

Suomen ilmastossa ei nurmen perustaminen läheskään aina onnistu tyydyttä-västi etupäässä kevätkesän kuivuudesta johtuen. On selvää, että sellaisille pienille, hennoille kasveille kuin kaikkien nurmikasvien oraat ovat, usein sattuvat viikkojen, jopa kuukausien sateettomat kaudet muodostavat suuren vaaran. Koko muokkauskerroksen ja ehkä vielä sen allakin olevan maan kuivuessa loppuu matalajuurisilta kasveilta veden ja sen mukana myös kasvinravintoaineiden saanti. Eri nurmikasvien välillä näyttää myöhemmässä kehitysvaiheessa olevan melkoisia eroja yleisessä kuivankestävyydessä, so. kyvyssä säilyä hengissä ja tuottaa satoa vähälläkin vedellä. Taimiasteella saattavat nuo erot olla vieläkin suuremmat.

Jotta tiedettäisiin, mistä erilaisuudet näissä suhteissa johtuvat, ja millä keinoilla nurmikasvien alkukehitystä ja siten nurmen perustamisen onnistumista. mahdollisesti voitaisiin varmentaa ja edistää, on tarpeen tuntea tärkeiden kasvien alkukehitys. Maanpäällisten osien kehitys tunnetaan jo jokseenkin riittävästi, mutta maanalaisten osien (juurien) kehitys, joka näissä suhteissa kuitenkin ilmeisesti on ratkaisevampi, tunnetaan paljon vaillinaisemmin.

Viljelyskasvien maanalaisiakin osia on aikojen kuluessa tutkittu aika paljon, mutta nurmikasvit ovat tässä suhteessa jääneet vähemmälle kuin muut. Vanhemmista tämän alan tutkimuksista ovat mm. Osvald (3) ja WeAver (7) esittäneet hyviä katsauksia. WEAvER (7) on tehnyt myös laajoja tutkimuksia nurmikasvien juurten kehityksestä. Witte (8) ja KöneKamp (2) ovat myös tehneet huomattavia tutkimuksia nurmikasvien juurista. Suomessa on KokKonen (1) tehnyt tutkimuksen koiranheinän juuristosta, mutta se ei koske sen alkukehitystä. PoHJakallio (4) on julkaissut useita tutkimuksia nurmikasvien, etupäässä timotein kuivankestävyydestä. Niissä on kiinnitetty huomiota myös juurten kehitykseen ja ulottuvaisuuksiin.

Tutkimusten ollessa asian laatuun nähden suhteellisen harvalukuiset näyttää aiheelliselle hankkia vielä lisäselvityksiä nurmikasvien maanalaisten osien kehityksestä, ennen muuta juurien tunkeutumisesta maahan. 
Havainnot kesällä $1950 \quad \mathrm{Vi}$ ik is ä.

Keväällä 1950 järjestettiin yliopiston tilalle Viikkiin Helsingin kaupungissa tri A. JäntıN toimesta koe, jossa on tarkoitus tutkia eri nurmikasvilajien suhtautumista erilaisiin typpilannoitusmääriin. Tämän koekentän pohjoispäähän varattiin alue, jossa tein käsilläolevaan tutkimukseen kuuluvat havainnot.

Alue oli edellisenä syksynä kynnetty neljännen vuoden nurmesta, mikä tutkimuksen kannalta ei kylläkään ollut hyvä järjestely, sillä maassa esiintyi sitkeää nurmiturvetta, ja mikä vielä pahempi, siinä oli myös juolavehnää, jonka juuret haittaavat pahasti juuristohavaintoja.

Maalaji koealueella on lähinnä hietasavea. Muokkauskerros on suunnilleen 20 cm paksu ja kohtalaisen humuspitoinen. Havaintoalueelta tehtiin sekä muokkauskerroksesta että pohjamaasta $(25-35 \mathrm{~cm}$ syvyydestä) Maatalouskoelaitoksen maatutkimusosastolla ns. viljavuustutkimus, jonka tulokset olivat:

muokkauskerros

pH-luku

helposti liukeneva fosforihappo, $\mathrm{kg} /$ ha $\mathrm{P}_{2} \mathrm{O}_{5} \quad \ldots \ldots \ldots$.

helposti liukeneva kali, $\mathrm{kg} / \mathrm{ha} \mathrm{K}_{2} \mathrm{O}$
5.9

13.4

270

2100 pohjamaa $25-35 \mathrm{~cm}$

5.8

10.5

60

1350

Koemaalle annettiin keväällä lannoitusta $1000 \mathrm{~kg} /$ ha kotkafosfaattia ja 300 $\mathrm{kg} /$ ha $40 \%$ kalisuolaa, mutta ei lainkaan typpilannoitteita. Maa muokattiin hieman tavallista perusteellisemmin. Nurmen suojaviljaksi kylvettiin $10.5 .150 \mathrm{~kg} / \mathrm{ha}$ Tammi ohraa. Suojaviljan kylvön jälkeen maa ladattiin ja sen jälkeen, 11. 5., kylvettiin nurmikasvien siemenet niitä varten järjestettyihin, $1.6 \mathrm{~m}$ leveihin ruutuihin. Näistä ruuduista oli jätetty $5 \mathrm{~m}$ pitkä osa ilman suojaviljaa. Kaikki siemen oli peitattu Certosan'illa. Nurmikasvien kylvö tehtiin Planet Jr. käsikoneilla $15 \mathrm{~cm}$ rivivälein. Kokeeseen otetut nurmikasvilajit, kannat ja käytetyt siemenmäärät olivat seuraavat:

\begin{tabular}{|c|c|c|c|}
\hline una-apila & Tammiston puna-apila & $\cdots$ & 16 \\
\hline alsikeapila & alsikeapila & 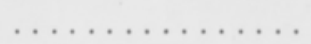 & 14 \\
\hline valkoapila & Nora $\ldots$ & & 12 \\
\hline timotei & kauppasiemen & & 15 \\
\hline koiranheinä & Tammiston koiranheinä & $\ldots \ldots \ldots \ldots \ldots$ & 25 \\
\hline urminata & nurminata & $\ldots \ldots \ldots \ldots \ldots \ldots$ & 35 \\
\hline onata & aronata & .. & 25 \\
\hline ittynurmikka & kauppasiemen & & 30 \\
\hline
\end{tabular}

Suojaviljana ollut Tammi ohra oli oraalla 24. 5. Se kasvoi hyvin ja oli jopa liiankin tiheää niukasta siemenmäärästä huolimatta. Se tuli tähkälle 28. 6. ja leikattiin 11. 8. Heinäkuun lopussa tehtyjen valoisuushavaintojen mukaan oli sen alla valoisuus 16 - $20 \%$ vastaavasta avoimella paikalla esiintyvästä (6), joten suojaviljan varjostus oli huomattava. Ohrasta saatu sato oli $3050 \mathrm{~kg} /$ ha jyviä.

Nurmikasvien oraalletulo alkoi $23-25$. 5. Hitain orastumaan oli aronata. Timotein orastuminen oli epätasaisempaa kuin muiden. Kaikkien lajien orastuminen oli 30. 5. jokseenkin täydellinen. 
Kasvukauden 1950 sääsuhteista esitetään seuraavassa yhteenveto säähavainnoista läheisellä Malmin lentokentällä, sillä Viikissä ei tehty säännöllisiä säähavaintoja:

\begin{tabular}{|c|c|c|c|}
\hline huhtikuu & & $\begin{array}{c}\text { lämpötila } \mathrm{C}^{\circ} \\
5.3\end{array}$ & $\begin{array}{c}\text { sademäärä mm } \\
102.7\end{array}$ \\
\hline toukokuu & $\ldots \ldots \ldots \ldots \ldots \ldots \ldots \ldots \ldots \ldots$ & 11.4 & 25.4 \\
\hline kesäkuu . & $\ldots \ldots \ldots \ldots \ldots \ldots \ldots \ldots \ldots \ldots \ldots \ldots \ldots \ldots$ & 16.1 & 11.1 \\
\hline heinäkuu & $\ldots \ldots \ldots \ldots \ldots$ & 17.0 & 37.2 \\
\hline elokuu... & $\ldots \ldots \ldots \ldots \ldots \ldots \ldots \ldots \ldots \ldots \ldots \ldots \ldots \ldots \ldots$ & 17.5 & 25.2 \\
\hline syyskuu . & 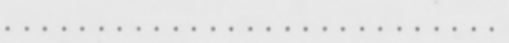 & 12.0 & 104.5 \\
\hline
\end{tabular}

Kasvukauden lämpösuhteet olivat jokseenkin suotuisat lukuunottamatta koleita kausia 14-17. 5. ja 26. 5.-2. 6. Kasvukausi oli hyvin vähäsateinen, kuten luvuista näkyy. Arvattavasti kuitenkin huhtikuun runsaan sademäärän ansiosta kuivuus kävi tuntuvasti haitalliseksi vasta elokuussa. Vasta 30. 8. tuli runsaampi sade. Koekasveista ilman suojaviljaa kasvaneet eivät kuitenkaan näyttäneet sanottavasti kärsivän kuivuudesta lukuunottamatta alsikeapilaa, jossa elokuun lopulla ilmeni pientä kuivuuden vaikutusta. Suojaviljan alla kasvaneet kasvit sensijaan kärsivät selvästi paljon kuivuudesta. Näin näytti olevan asianlaita varsinkin sen jälkeen, kun suojavilja oli korjattu.

Havaintojen suoritus. Kaikista kokeessa mukana olleista nurmikasveista tehtiin kasvukauden kuluessa useaan otteeseen havaintoja sekä maanpäällisten että varsinkin maanalaisten osien kehityksestä. Ilman suojaviljaa olleista ruuduista tehtiin havainnot kesäkuun lopulla (päivämäärät on mainittu havaintoselostuksissa), heinäkuun alussa ja lopussa, elokuun keskivaiheilla sekä syyskuun keskivaiheilla. Suojaviljan alla kasvaneista kasveista tehtiin havainnot vain suojaviljan leikkuun jälkeen elokuun ja syyskuun keskivaiheilla. Maanalaisten osien tutkimisessa käytettiin samoja menetelmiä kuin allekirjoittanut on käyttänyt aikaisemminkin (5). Juuristotutkimuksissa käytettiin yleensä sekä vedessä huuhtomista että ns. suoraa menetelmää lukuunottamatta heinäkuun lopulla tehtyjä havaintoja, joissa käytettiin vain suoraa menetelmää. Syyskuun alussa niitettiin osa ilman suojaviljaa olleista koeruuduista sadon selvittämiseksi, mutta suojaviljan alla olleilla ruuduilla ei ollut mitään niitettävää.

\section{Puna-apila}

1. I lman suojavilja

a. Maanpäälliset osat

19. 6. Taimisto tasainen. Sirkkalehdet ovat vielä vihreät. Niiden lisäksi yksi 1-osainen ja yksi tavallinen 3-osainen lehti sekä uusia kehittymässä.

5. 7. Tainten korkeus $10-12 \mathrm{~cm}$. Sirkkalehdet ovat jo hävinneet, mutta 1 -osainen varsilehti on vielä vihreä. 3-osaisia lehtiä yleisimmin $3 \mathrm{kpl}$ ja uusia kehittymässä.

24. 7. Kasvuston korkeus $17-20 \mathrm{~cm}$. Yksilöissä yleensä $2-4$ versoa, joissa kussakin $3-6$ lehteä. 3-4 ensimmäistä lehteä jo kuihtunut.

10. 8. Kasvuston korkeus $30-35 \mathrm{~cm}$. Yksilöissä $2-5$ versoa. Muutamissa jo kukkamykerö.

13. 9. Kasvu edelleen sangen hyvä. Yksilöissä 10-12 versoa. Kukinta yleistä, mutta ei runsasta.

26. 9. Kasvu jatkuvasti hyvä. Kukinta jatkuu. Niitetyllä kohdalla odelman kasvu vähäistä.

Sato korjattiin osalta ruutua 5.9., jolloin saatiin $359 \mathrm{~g} / \mathrm{m}^{2}$ kuiva-ainetta. 


\section{b. Maanalaiset osat}

19. 6. Pääjuuri selvä, suurin syvyys $7-11 \mathrm{~cm}$. Jo pieniä juuriäkämiä.

5. 7. Pääjuuret niskasta n. 2 mm läpim., erottuvat selvinä n. 25 cm syvyyteen. Juurien suurin syvyys $35 \mathrm{~cm}$. Pieniä juuriäkämiä harvahkossa, sisästä vaalean punaisia.

24. 7. Pääjuuret niskasta $3-4 \mathrm{~mm}$ läpim. Juurien suurin syvyys $\mathrm{n} .50 \mathrm{~cm}$.

10. 8. Pääjuuret niskasta $5-7 \mathrm{~mm}$ läpim., esiintyvät selvinä $\mathrm{n} .45 \mathrm{~cm}$ syvyyteen. Juurien suurin syvyys $75 \mathrm{~cm}$. Juuriäkämiä n. $35 \mathrm{~cm}$ syvyyteen asti, pieniä, sisästä punaruskeita.

13. 9. Suurimmat pääjuuret niskasta $10-11 \mathrm{~mm}$ läpim., ja vielä $40 \mathrm{~cm}$ syvyydessäkin $2-3 \mathrm{~mm}$. Suurin todettu juurien syvyys $105 \mathrm{~cm}$. Alimmat juuriäkämät $65 \mathrm{~cm}$ syvyydessä.

2. Suojaviljan alla kasvaneet

a. Maanpäälliset osat

15. 8. Taimisto tasainen, mutta harvahko. Taimet ovat pieniä, mutta elinvoimaisen näköisiä. Versomista ei vielä esiinny.

19. 9. Taimisto verraten vähän kehittynyt edellisestä, korkeus $7-10 \mathrm{~cm}$. Kookkaimmissa taimissa $3-5$ versoa, joissa kussakin $3-5$ lehteä.

b. Maanalaiset osat

15. 8. Pääjuuret niskasta $1-2 \mathrm{~mm}$ läpim., esiintyvät selvinä $7 \mathrm{~cm}$ syvyyteen. Suurin todettu juurien syvyys 13-14 cm. Juuriäkämiä suhteellisen paljon, yleensä pieniä, mutta jokin kookkaampi seassa, sisästä ruskeita.

19. 9. Pääjuuret tyvestä $2-4 \mathrm{~mm}$ läpim. Juurien suurin syvyys $50 \mathrm{~cm}$.

\section{Alsikeapila}

1. Ilman suojaviljaa kasvaneet

a. Maanpäälliset osat

19. 6. Taimisto tasainen. Sirkkalehdet jo kellastuneet. Yksi 1-osainen ja 2-3 3-osaista lehteä.

6. 7. Kasvuston korkeus $5-7 \mathrm{~cm}$. Taimista alimmat lehdet jo kuivettuneet. Eläviä varsilehtiä $4-6$ kpl. Useissa yksılöissä versominen jo alussa.

27. 7. Kasvuston korkeus $6-10 \mathrm{~cm}$. Taimissa $3-6$ versoa, joissa $3-7$ lehteä.

11. 8. Kasvusto käynyt hieman epätasaiseksi ilmeisesti kuivuuden johdosta. Korkeus yleensä 10 - 15 $\mathrm{cm}$, mutta muutama yksilö jopa $25 \mathrm{~cm}$. Versoja yleisesti 3-7. Muutama yksilö jo kukassa.

12. 9. Kasvuston korkeus $30-40 \mathrm{~cm}$. Kukkii yleisesti, joskaan ei runsaasti.

26. 9. Kasvu jatkuvasti hyvä, joskin lehdille on ilmestynyt runsaasti härmää. Niitetyllä alalla on odelman kasvu vähäistä.

Sato korjattin osalta rutua 5. 9., jolloin saatiin $288 \mathrm{~g} / \mathrm{m}^{2}$ kuiva-ainetta.

b. Maanalaiset osat

19. 6. Juurien suurin syvyys $8-10 \mathrm{~cm}$. Jo pieniä juuriäkämiä.

6. 7. Pääjuuret tyvestä $1-2 \mathrm{~mm}$ läpim. Suurin todettu syvyys halkeamien kohdalla $25 \mathrm{~cm}$, muualla vähemmän. Keskikokoiset juuriäkämät etupäässä pääjuuressa.

27. 7. Pääjuuret niskasta $3-4 \mathrm{~mm}$ läpim., esiintyvät selvinä vain $7-10 \mathrm{~cm}$, jonka alapuolella haaraantuvat runsaasti. Suurin todettu syvyys $30 \mathrm{~cm}$. Juuriäkämiä verraten harvassa, pienehköjä, sisästä vaalean ruskeita.

11. 8. Pääjuuret niskasta 4-6 mm läpim. Esiintyvät muutamissa tapauksissa selvinä 50 cm syvälle, mutta ei läheskään aina. Suurin todettu syvyys $75 \mathrm{~cm}$ halkeamien kohdalla, muualla vähemmän. Juuriäkämiä esiintyy $45 \mathrm{~cm}$ asti.

12. 9. Pääjuuret niskasta $5-8 \mathrm{~mm}$ läpim. Haaraantuvat runsaasti, mutta yleensä esiintyvät selvinä $55 \mathrm{~cm}$ syvyyteen. Suurin todettu juurien syvyys $95 \mathrm{~cm}$. Juuriäkämiä $55 \mathrm{~cm}$ asti, kookkaita, verraten löysiä, sisästä ruskeita. Lähellä maanpintaa runsaasti melkein valkeita, aivan nuoria juuria, jotka ovat nopeasti kasvaneet sateiden ansiosta. 
2. Suojaviljan alla kasvaneet

a. Maanpäälliset osat

15. 8. Taimisto melko tiheä ja tasainen, mutta taimet ovat hyvin pieniä. Versomista ei lainkaan, lehtiä $3-7 \mathrm{kpl}$.

19. 9. Taimissa ei vieläkään versomista, lehtiä $4-8 \mathrm{kpl}$. Kasvuston korkeus $3-4 \mathrm{~cm}$.

\section{b. Maanalaiset osat}

15. 8. Pääjuuret tyvestä $1-2 \mathrm{~mm}$ läpim., esiintyvät selvinä $5-6 \mathrm{~cm}$, suurin todettu syvyys $12-13$ cm. Juuriäkämät pieniä, sisästä vihreitä tai ruskean vihreitä.

19. 9. Pääjuuret jatkuvasti tyvestä $1-2 \mathrm{~mm}$ läpim., syvyys yleensä $12-14 \mathrm{~cm}$, mutta eräissä yksilöissä jopa $25 \mathrm{~cm}$. Juuriäkämiä melko paljon, kookkaita, sisästä punaruskeita.

\section{Valkoapila}

1. I $l$ man suojavilja kasvaneet

a. Maanpäälliset osat

19. 6. Orastuminen tasaista. Tainten korkeus $1-2 \mathrm{~cm}$. Sirkkalehtien lisäksi yksi 1 -osainen ja yksi 3-osainen lehti.

5. 7. Tainten korkeus $5-6 \mathrm{~cm}$. Tavallisia varsilehtiä $7-10 \mathrm{kpl}$. Kookkaimmissa yksilöissä jo havaittavissa rönsyjen alkua.

24. 7. Kasvuston korkeus $10-20 \mathrm{~cm}$. Rönsyjä jo paljon, pituus $5-10 \mathrm{~cm}$. Muutama kukinto.

10. 8. Kasvuston korkeus $15-18 \mathrm{~cm}$. Rönsyjä $2-6 \mathrm{kpl}$ yksilöä kohti, pituus $10-15 \mathrm{~cm}$, ovat jo juurtumassa maahan. Kukintoja harvakseen.

12. 9. Kasvusto tasoittunut suuresti sateitten ansiosta, korkeus n. 20 cm. Rönsyjä yksilöä kohti jopa toistakymmentä, pituus $15-20 \mathrm{~cm}$, usea haaraantunut, vahvasti maahan juurtuneet. Kukinta runsasta.

26. 9. Kasvu edelleen hyvä. Kukkiminen loppunut. Niitetyllä kohdalla melko hyvä odelma.

Sato korjattiin osalta ruutua 5. 9., jolloin saatiin $157 \mathrm{~g} / \mathrm{m}^{2} \mathrm{kuiva}$-ainetta.

\section{b. Maanalaiset osat}

19. 6. Juurien suurin syvyys $7-13 \mathrm{~cm}$. Runsaasti pieniä juuriäkämiä.

5. 7. Pääjuuret tyvestä n. 1 mm läpim. Juurien suurin syvyys vaihtelee paljon eri yksilöillä ollen yleisimmin välillä $10-15 \mathrm{~cm}$, suurin havaittu syvyys $20 \mathrm{~cm}$. Juuriäkämiä on melko harvassa, mutta ne ovat kookkaita, sisästä heleän punaisia.

24. 7. Juurien suurin syvyys yleensä $20-25 \mathrm{~cm}$, muutamissa yksilöissä $35 \mathrm{~cm}$.

10. 8. Pääjuuret tyvestä $3-4 \mathrm{~mm}$ läpim. Muokkauskerroksessa on tasainen, melko tiheä juuristoverkko, mutta syvemmälle menee vain verraten harvoja juuria, jotka voivat tunkeutua $65 \mathrm{~cm}$ syvälle. Alimmat juuriäkämät $25 \mathrm{~cm}$ syvyydessä.

12. 9. Pääjuuret tyvestä $3-5 \mathrm{~mm}$ läpim., esiintyvät selvinä $50 \mathrm{~cm}$ syvyyteen asti. Suurin todettu juurien syvyys $105 \mathrm{~cm}$. Juuria on runsaimmin halkeamien kohdalla. Juuriäkämiä on runsaasti, ne ovat melko kookkaita $45 \mathrm{~cm}$ asti, harvassa ja pienikokoisia $85 \mathrm{~cm}$ asti. Maan pintaosassa $10 \mathrm{~cm}$ syvyyteen runsaasti aivan nuoria, ilmeisesti vasta sateitten jälkeen muodostuneita juuria.

2. Suojaviljan alla kasvaneet

a. Maanpäälliset osat

15. 8. Taimisto melko tasainen. Taimet hyvin pieniä ja hentoja, mutta elinvoimaisen näköisiä. Rönsyistä ei merkkiäkään. Lehtiä yksilöissä $3-10 \mathrm{kpl}$.

19. 9. Taimisto tasainen. Korkeus $2-3 \mathrm{~cm}$. Ei vieläkään versomista tai rönsyilyä.

b. Maanalaiset osat

15. 8. Pääjuuret niskasta n. $1 \mathrm{~mm}$ läpim., esiintyvät selvinä $10 \mathrm{~cm}$ syvyyteen, suurin juurien syvyys $13 \mathrm{~cm}$. Muutama kookas juuriäkämä, sisästä ruskea.

19. 9. Pääjuuret niskasta $1-1.5 \mathrm{~mm}$ läpim. Juurien suurin syvyys yleisesti $\mathrm{n} .10 \mathrm{~cm}, \mathrm{muutamissa}$ tapauksissa $30 \mathrm{~cm}$. Juuriäkämiä $20 \mathrm{~cm}$ asti, harvassa, kookkaita, sisästä ruskeita. 


\section{Timotei}

1. I lman suojaviliaa kasvaneet

a. Maanpäälliset osat

19. 6. Orastuminen epätasaista. Taimia eri kehitysvaiheissa, suurimmissa jo 4 lehteä, pienimmissä. vasta 2 .

11. 7. Orastumisen epätasaisuus näkyy vielä selvästi. Kookkaimmissa jo $2-3$ versoa, joissa $2-3$ lehteä. Kasvuston korkeus $4-6 \mathrm{~cm}$.

24. 7. Taimisto jatkuvasti epätasainen. Osassa taimia $2-3$ versoa, mutta osa ei vielä lainkaan versonut. Versoa kohti $3-5$ lehteä. Kasvuston korkeus $5-10 \mathrm{~cm}$.

14. 8. Osassa taimista jo korsi ja tähkä. Versoja $3-5$, muutamissa yksilöissä jopa 7 . Kookkaimpiin yksilöihin on ilmestynyt kahukärpäsen toukkia. (Myöhemmin ilmeni niiden tuhoa huomattavasti, josta johtuen muutama yksilö kuoli, ja monet kärsivät paljon. Sateitten tultua elo-syyskuun vaihteessa niiden tuhot loppuivat.)

15. 9. Taimisto harva, mutta yksilöt kookkaita. Yleisesti $3-5$ versoa, joista voimakkaimmassa korsi ja tähkä.

26. 9. Kasvu virkeä. Niitetyllä alalla odelman kasvu heikko.

Sato korjattiin osalta ruutua 5. 9., jolloin saatiin $35 \mathrm{~g} / \mathrm{m}^{2} \mathrm{kuiva-ainetta.}$

b. Maanalaiset osat

19. 6. Maanalainen korsi, mesokotyyli, 0.5-1 cm. Sekundääriset juuret vasta $2-3 \mathrm{~cm}$ pitkiä. Primääriset itämisjuuret menevät $6-7 \mathrm{~cm}$ syvyyteen.

11. 7. Primääriset juuret hyvin hentoja, menevät $12-13 \mathrm{~cm}$ syvälle. Huomattavasti paksumpia sekundäärisiä juuria jo paljon, pituus $10-12 \mathrm{~cm}$, leviävät etupäässä sivusuuntaan, joten suurin syvyys vain $5-7 \mathrm{~cm}$.

24. 7. Primääriset juuret hyvin hentoja, ja niiden rappeutuminen on ilmeisesti alkamassa, mutta ovat vielä todennäköisesti toimintakykyisiä. Sekundäärisiä juuria on runsaasti, ne ovat melko tukevia, suurin pituus $15 \mathrm{~cm}$. Suurin todettu syvyys $13 \mathrm{~cm}$.

14. 8. Primääristen juurien kehitys loppunut, ja ne ovat hyvin hauraita. Sekundääristen juurien pituus yleisesti $15 \mathrm{~cm}$. Suurin todettu syvyys $13 \mathrm{~cm}$.

15. 9. Primäärinen juuristo rappeutunut. Sekundäärinen juuristo on runsas. Nuorimmat juuret ovat melko tukevia. Pituus yleisesti $15-20 \mathrm{~cm}$. Leviävät vinosti alaspäin. Suurin havaittu syvyys $18 \mathrm{~cm}$.

2. Suojaviljan alla kasvaneet

a. Maanpäälliset osat

15. 8. Taimisto aukkoinen. Taimet erittäin pieniä ja hentoja. Yksilöissä $3-5$ lehteä, joista alimmat kellastuneet. Ei merkkiäkään versomisesta.

19. 9. Tainten korkeus $5-10 \mathrm{~cm}$. Yksilöissä yleensä vain yksi verso, mutta muutamassa harvassa $2-3$. Versossa $3-4$ lehteä.

b. Maanalaiset osat

15. 8. Primääriset juuret vielä hyvässä kunnossa. Sekundäärisiä juuria $10-15$ kpl., hyvin hentoja nekin, runsaasti haaraantuneita. Suurin todettu syvyys $8 \mathrm{~cm}$.

19. 9. Primääriset juuret jatkuvasti kunnossa. Sekundääriset juuret paljon lisääntyneet edellisen tarkastelun jälkeen. Osa niistä on aivan valkeita, ilmeisesti aivan äskettäin muodostuneita. Pisimmät juuret (sek.) $11 \mathrm{~cm}$, suurin todettu syvyys $10 \mathrm{~cm}$.

\section{Koiranheinä}

1. I lman suojaviljaa kasvaneet

a. Maanpäälliset osat

19. 6. Taimisto kohtalainen, joskin hieman aukkoinen. Taimissa 3 lehteä, ei vielä versoja.

6. 7. Kasvusto paljon tasoittunut, korkeus $10-15 \mathrm{~cm}$. Useissa taimissa jo $2-4$ versoa.

24. 7. Kasvusto hyvä, korkeus $10-20 \mathrm{~cm}$. Useimmissa taimissa $5-6$ versoa, joissa kussakin $2-5$ lehteä. 
10. 8. Kasvu edelleen hyvä. Kasvuston korkeus $20 \mathrm{~cm}$ jopa ylikin. Taimissa versoja usein yli 10 , muutamissa jo korren alku.

13. 9. Kasvu jatkuvasti hyvin rehevä. Kasvuston korkeus n. $35 \mathrm{~cm}$. Useissa yksilöissä yli 20 versoa, joissa kussakin $3-5$ lehteä. Korsia vain muutamia harvoja.

26. 9. Kasvu edelleen hyvä. Niitetyllä alalla odelman kasvu erittäin hyvä.

Sato korjattiin osalta ruutua 5.9 ., jolloin saatiin $151 \mathrm{~g} / \mathrm{m}^{2} \mathrm{kuiva-ainetta.}$

b. Maanalaiset osat

19. 6. Mesokotyyli yleensä $0-0.5 \mathrm{~cm}$, muutamissa harvoissa jopa $4 \mathrm{~cm}$. Primääriset juuret $8-10$ $\mathrm{cm}$ pitkiä. Sekundääriset juuret puhkeamassa.

6. 9. Mesokotyyli ja primääriset juuret hyvin hentoja. Sekundääriset juuret hyvin kehittyneitä ja tukevia, pituus $10-12 \mathrm{~cm}$, suurin syvyys $10 \mathrm{~cm}$.

24. 7. Primäärisiä juuria on enää vaikea havaita, eivät näytä enää olevan kunnossa. Sekundäärisiä juuria on paljon, vanhimmat niistä ovat hentoja, nuoremmat yhä tukevampia. Kasvusuunta lähellä vaakasuoraa. Suurin pituus $22 \mathrm{~cm}$, suurin todettu syvyys $15 \mathrm{~cm}$.

10. 8. Primääriset juuret näyttävät kokonaan kuolleen. Sekundäärisiä juuria on paljon, $20-30$ jopa enemmän. Leviävät etupäässä sivusuuntaan, pituus $20 \mathrm{~cm}$ ja ylikin. Suurin todettu syvyys $16 \mathrm{~cm}$.

13. 9. Primääristä juuristoa ei enää löydy. Sekundääristen juurien määrä ja pituus yhä lisääntynyt, pisimmät juuret $30 \mathrm{~cm}$, suunta vinosti alas. Suurin todettu syvyys $23 \mathrm{~cm}$.

2. Suojaviljan alla kasvaneet

a. Maanpäälliset osat

15. 9. Taimisto melkoisen epätasainen. Taimet ovat hyvin hentoja ja nuutuneen näköisiä, eivätkä vaikuta elinvoimaisille. Lehtiä $3-\mathbf{4}$, joista alimmat kuivettuneet. Versomisesta ei merkkiäkään. 19. 9. Taimisto huomattavasti virkistynyt ja tasoittunut. Korkeus $6-10 \mathrm{~cm}$, lehtiä $3-5 \mathrm{kpl}$. Vain muutamassa yksilössä versomisen alkua.

b. Maanalaiset osat

15. 8. Primäärinen juuristo vielä vallitseva. Suurin todettu syvyys $10 \mathrm{~cm}$. Sekundäärisiä juuria vain $1-4 \mathrm{kpl}$, hentoja ja haaraisia.

19. 9. Primäärinen juuristo vielä hyvässä kunnossa, joskaan ei ole kasvanut edellisestä. Sekundäärinen juuristo jo kookkaampi. Pisimmät juuret $20 \mathrm{~cm}$, suurin todettu syvyys $11 \mathrm{~cm}$.

\section{Nurminata}

1. I lman suojaviljaa kasvaneet

a. Maanpäälliset osat

19. 6. Orastuminen tasaista, taimissa $2-3$ lehteä.

7. 7. Tainten kehittyminen on ollut melko ripeää. Useimmissa yksilöissä 2-4 versoa. Kasvuston korkeus $7-12 \mathrm{~cm}$.

24. 7. Kasvusto rehevä, korkeus $10-15 \mathrm{~cm}$. Yksilöissä versoja $5-7$, versoa kohti $3-4$ lehteä.

11. 8. Kasvu edelleen hyvä. Yksilöissä versoja $5-9 \mathrm{kpl}$.

15. 9. Kasvu jatkuvasti hyvä. Versoja yleisesti $6-10$, joissa $4-7$ lehteä. Ei merkkiäkään korren kasvusta.

26. 9. Kasvu edelleen hyvä. Muutamissa vanhemmissa lehdissä hieman ruostetta .Niitetyllä alalla hyvä odelma.

Sato korjattiin osalta ruutua 5. 9., jolloin saatiin $56 \mathrm{~g} / \mathrm{m}^{2}$ kuiva-ainetta.

b. Maanalaiset osat

19. 6. Mesokotyyli yleensä $0-0.5 \mathrm{~cm}$, muutamissa harvoissa jopa $3 \mathrm{~cm}$. Primääriset juuret aivan vallitsevat, suurin syvyys $6-13 \mathrm{~cm}$. Sekundääriset juuret kehittymässä.

7. 7. Primääristen juurten kasvu näyttää loppuneen. Ne ovat hyvin hentoja, suurin syvyys 10 - $13 \mathrm{~cm}$. Sekundäärisiä juuria on hyvin runsaasti, suurin pituus $10 \mathrm{~cm}$. 
24. 7. Primääriset juuret eivät ole edellisestä lainkaan kehittyneet, ne ovat hauraita, mutta ilmeisesti vielä toimintakykyisiä. Sekundääriset juuret ovat runsaat ja voimakkaat, läpim. n. $1 \mathrm{~mm}$, pituus $5-12 \mathrm{~cm}$, leviävät vinosti alas.

11. 8. Primääriset juuret huonon näköisiä. Sekundääriset juuret ovat vielä paljon lisääntyneet, nuorimmat ovat kaikkein tukevimpia, paksuus yli $1 \mathrm{~mm}$. Pituus $10-20 \mathrm{~cm}$, leviävät etupäässä sivusuuntaan, suurin todettu syvyys $15 \mathrm{~cm}$.

15. 9. Primäärisiä juuria on enää vaikea havaita. Sekundääriset juuret ovat hyvin runsaat, pisimmät $25 \mathrm{~cm}$ pitkiä, suurin todettu syvyys $18 \mathrm{~cm}$.

2. Suojaviljan alla kasvaneet

a. Maanpäälliset osat

15. 8. Taimisto on kohtalaisen tasainen. Taimet ovat hyvin hentoja ja kelmeitä, mutta kuitenkin elinkykyisen näköisiä. Kookkaimmissakaan ei näy merkkiäkään versomisesta. Lehtiä on $3-5$, joista alimmat ovat kuivettuneet.

19. 9. Taimisto selvästi, joskin vähän kehittynyt edellisestä, korkeus $7-10$. Muutamissa yksilöissä on $2-3$ versoa, mutta pääosa ei vielä versonut. Lehtiä versossa $3-5$.

\section{b. Maanalaiset osat}

15. 8. Primääriset juuret hyvässä kunnossa ja hyvin haaraiset. Sekundäärisiä juuria vähän, korkeintaan $6 \mathrm{kpl}$. Suurin todettu juurten syvyys $10-11 \mathrm{~cm}$.

19. 9. Primääriset juuret ilmeisesti vielä kunnossa. Sekundääriset juuret paljon lisääntyneet, pisimmät $18 \mathrm{~cm}$, suurin todettu syvyys $12 \mathrm{~cm}$.

\section{Aronata}

1. I man suojaviljaa kasvaneet

\section{a. Maanpäälliset osat}

19. 6. Taimisto on aukkoinen ja epätasainen. Taimia on vasta itäneitä ja sellaisia, joissa on jo kaksi versoa. Pääversossa tavallisesti $3-4$ lehteä.

7. 7. Taimisto jonkinverran tasoittunut, korkeus $4-6 \mathrm{~cm}$. Taimet hyvin kehittyneet, yleisesti $3-4$ versoa, ja rönsyily on alkamassa.

27. 7. Kasvuston korkeus $6-10 \mathrm{~cm}$. Taimissa versoja 4-6, joissa kussakin $3-5$ lehteä. Rönsyily on alussa.

14. 8. Kasvuston korkeus $10-13 \mathrm{~cm}$. Muutamissa kookkaimmissa yksilöissä on jopa 30 versoa, yleisesti kuitenkin vain $4-7$. Rönsyjen pituus $3-5 \mathrm{~cm}$.

12. 8. Kasvusto melko hyvän näköinen, korkeus $13-16 \mathrm{~cm}$. Versoja tavallisimmin $5-10$. Rönsyjä runsaasti sekä maan päällä että alla.

26. 9. Kasvu hyvä. Ei korren alkuja. Niitetyllä kohdalla kohtalainen odelma.

Sato korjattiin osalta ruutua 5. 9., jolloin saatiin $32 \mathrm{~g} / \mathrm{m}^{2}$ kuiva-ainetta.

b. Maanalaiset osat

19. 6. Mesokotyyli $0.5-1 \mathrm{~cm}$. Primääriset juuret $5-7 \mathrm{~cm}$ pitkiä, sekundäärisetkin jo $1-5 \mathrm{~cm}$. 7. 7. Primääristen juurien kehitys näyttää jo loppuvan. Sekundääriset juuret ovat runsaat ja hyvin kehittyneet. Suurin syvyys $10-11 \mathrm{~cm}$.

27. 7. Primääriset juuret ilmeisesti vielä elossa, suurin syvyys $10 \mathrm{~cm}$. Sekundäärisiä juuria on runsaasti ja ne ovat tummia ja haaraisia. Pituus $10-15 \mathrm{~cm}$, suurin syvyys $12 \mathrm{~cm}$.

14. 8. Primäärinen juuristo hauras ja huonon näköinen. Sekundäärinen juuristo on aivan vallitseva. Yksityisiä juuria ei ole varsin monia, mutta ne ovat hyvin haarajsia. Suurin pituus $25 \mathrm{~cm}$ ja suurin todettu syvyys $15 \mathrm{~cm}$.

12. 9. Primäärinen juuristo on rappeutunut. Sekundäärinen juuristo on runsas, väriltään tumma. Suurin todettu syvyys $20 \mathrm{~cm}$. 
2. Suojaviljan alla kasvane e!

a. Maanpäälliset osat

15. 8. Taimisto melko tasainen, mutta taimet aivan pieniä ja nuutuneen näköisiä. Vain muutamassa harvassa 2 versoa ja rönsyn alku. Versoissa lehtiä $3-5$, joista alimmat kuivuneet.

19. 9. Tainten korkeus $6-9 \mathrm{~cm}$. Useimmissa $2-5$ versoa, muutamissa jopa 7 , joissa $2-4$ lehteä. Rönsyily vielä aivan vähäistä.

\section{b. Maanalaiset osat}

15. 8. Primäärinen juuristo täysin kunnossa, joskin hyvin pieni ja hento. Sekundäärisetkin juuret ovat hentoja, niitä on $5-10 \mathrm{kpl}$. Suurin todettu syvyys $7 \mathrm{~cm}$.

19. 9. Primäärinen juuristo on vielä kunnossa, mutta ei ole lainkaan kasvanut edellisestä. Sekundäärinen juuristo on jo vallitseva. Pisimmät juuret $15 \mathrm{~cm}$, suurin syvyys $10 \mathrm{~cm}$.

\section{Niittynurmikka}

1. I lman suojaviliaa kasvaneet

a. Maanpäälliset osat

19. 6. Taimisto tasainen. Taimissa $2-3$ lehteä.

11. 7. Versominen jo alussa, muutamissa jo 2 versoa, useissa silmuja. Lehtiä $3-5 \mathrm{kpl}$.

27. 7. Kasvuston korkeus $5-7 \mathrm{~cm}$. Versoja yleisesti $3-5$, joissa $2-4$ lehteä. Muutamissa harvoissa rönsyn alku.

14. 8. Kasvuston korkeus $10-12 \mathrm{~cm}$. Versoja yleisesti $3-7$. Rönsyily alkaa olla yleistä. Rönsyjen pituus $5-8 \mathrm{~cm}$.

12. 9. Kasvuston korkeus $10-15 \mathrm{~cm}$. Versoja voi olla jopa yli 10 , joissa $4-6$ lehteä. Rönsyjä runsaasti sekä maan päällä että alla, pituus $5-10 \mathrm{~cm}$. Ei korren alkuja.

26. 9. Kasvu hyvä. Niitetyllä alalla odelma heikkoa.

Sato yritettiin korjata 5. 9., mutta saatiin vain mitättömän vähän

b. Maanalaiset osat

19. 6. Mesokotyyli $0-5 \mathrm{~cm}$. Primääristen juurten suurin syvyys $6-8 \mathrm{~cm}$. Sekundääriset juuret puhkeamassa.

11. 7. Primääristen ja sekundääristen juurten määrät sunnnilleen yhtä suuret. Suurin syvyys $10 \mathrm{~cm}$.

27. 7. Primääristen juurien osuus vieläkin huomattava, suurempi kuin muilla heinäkasveilla vastaavassa vaiheessa. Tiheissä kohdissa voi olla yksilöitä, joilla on vain primäärisiä juuria, mutta siitä huolimatta voi olla 2 versoa. Primääristen juurien suurin syvyys $12 \mathrm{~cm}$. Sekundääriset juuret leviävät etupäässä sivusuuntaan, pituus $10-15 \mathrm{~cm}$, suurin syvyys $10 \mathrm{~cm}$.

14. 8. Primäärinen juuristo alkaa rappeutua. Sekundääristen juurten pituus n. $15 \mathrm{~cm}$, suurin syvyys $12-13 \mathrm{~cm}$.

12. 9. Primäärinen juuristo rappeutunut. Sekundääristen juurten määrä on edellisestä huomattavasti lisääntynyt, mutta nuoremmat juuret ovat melko lyhyitä. Suurin todettu syvyys $15 \mathrm{~cm}$.

2. Suojaviljan alla kasvaneet

\section{a. Maanpäälliset osat}

15. 8. Taimisto melko tasainen. Taimet hyvin pieniä ja hentoja. Lehtiä $3-5$, joista alimmat kuivettuneet. Versomista ei esiinny, mutta muutamissa taimissa on rönsyn alku.

19. 9. Taimet yhä hyvin pieniä. Vain harvoissa on 2 versoa. Rönsyn alkuja yleisemmin.

b. Maanalaiset osat

15. 8. Primäärinen juuristo hyvin pieni ja hento. Sekundäärisiä juuria 5-10, hentoja ja haaraisia. Suurin todettu syvyys $5-6 \mathrm{~cm}$.

19. 9. Primäärinen juuristo ilmeisesti yhä kunnossa, joskaan ei ole kasvanut edellisestä. Sekundäärisiä juuria melko paljon, pisimmät $12 \mathrm{~cm}$, suurin syvyys $8 \mathrm{~cm}$. 


\section{Havaintojen tarkastelua.}

Kaikkien a p i l o i d e n kehitys on ollut ilman suojaviljaa olleella alalla ripeää. Nopein on ollut puna-apila, mutta toisetkaan lajit eivät ole jääneet paljoa jälkeen. Syyskuun 5. p:nä suoritetussa niitossa saadut tulokset:

$\begin{array}{cccc}\text { puna-apila } & 359 & \mathrm{~g} / \mathrm{m}^{2} & \text { kuiva-ainetta } \\ \text { alsikeapila } & 288 \\ \text { valkoapila } & 157\end{array}$

kuvastavat hyvin eri apilalajien ensimmäisen kesän kehitystä. Juurten syvyyskasvu oli puna-apilalla nopeaa alusta alkaen, ja siinä päästiin syyskuun puoliväliin mennessä yli metrin syvyyteen. Alsike- ja valkoapilan juurten syvyyskasvu oli aluksi hieman hitaampaa, mutta syyskuun puolivälissä oli valkoapilan juurien suurin syvyys sama kuin puna-apilan ja alsikeapilan vain vähän pienempi.

Suojaviljan alla kasvaneet apilan taimet kehittyivät hyvin huonosti, ja toipuminen suojaviljan korjuun jälkeen oli hidasta. Juurien suurin syvyys oli elokuun puolivälissä kaikilla lajeilla vain vähän yli $10 \mathrm{~cm}$, kun se ilman suojaviljaa kasvaneilla oli samaan aikaan $65-75 \mathrm{~cm}$. Suojaviljan korjuun jälkeen oli juurten syvyyskasvu ripeää, sillä suurin syvyys tuli n. kaksinkertaiseksi kuukauden aikana ollen syyskuun puolivälissä $20-30 \mathrm{~cm}$.

T i m o t e i n alkukehitys oli ilman suojaviljaakin olleella alalla hidas. Siitä huolimatta osa kasviyksilöistä ehti syksyyn mennessä kehittää korren ja tähkän. Syyskuun 5. p:nä saatu sato, $35 \mathrm{~g} / \mathrm{m}^{2} \mathrm{k}$.a., on apiloiden vastaavaan verrattuna pieni. On kuitenkin otettava huomioon, että timotein kasvusto oli harva ja vielä kahukärpänenkin ahdisti sitä. Erityisesti juuriston hidas syvyyskasvu kiinnittää huomiota. Vielä elokuun puolivälissä juurten suurin syvyys oli vain $13 \mathrm{~cm}$, ja syyskuun puoliväliin mennessä päästiin vasta $18 \mathrm{~cm}$ syvyyteen.

Suojaviljan alla on timotein kehitys ollut erittäin huonoa, ja toipuminen suojaviljan korjuun jälkeen kävi hitaasti. Juuristo saavutti syyskuun puoliväliin mennessä vain $10 \mathrm{~cm}$ syvyyden.

K o ir a nhein än ja n u rmin a da n kummankin kehitys on ollut hyvin samantapainen. Maanpäälliset osat ovat ilman suojaviljaa olleella alalla kehittyneet huomattavasti rehevämmin ja nopeammin kuin muiden heinien, koiranheinän vielä rehevämmin kuin nurminadan. Syyskuun 5. p:nä tehdyssä niitossa antoivat: koiranheinä 151 ja nurminata $56 \mathrm{~g} / \mathrm{m}^{2} \mathrm{k}$.a. Koiranheinään ilmestyi loppukesällä muutama korsi röyhyineen, mutta nurminataan ei ainoaakaan. Juuristojen kehitys on sekin ollut kummallakin hyvin samanlainen. Juuret menivät nopeasti $\mathrm{n} .10 \mathrm{~cm}$ syvyyteen, mutta siitä edelleen on kehitys ollut hidas, koiranheinällä kuitenkin hieman nopeampaa kuin nurminadalla. Syyskuun puolivälissä oli juurten suurin syvyys koiranheinällä $23 \mathrm{~cm}$ ja nurminadalla $18 \mathrm{~cm}$.

Suojaviljan alla sekä koiranheinä että nurminata kehittyivät hyvin huonosti. Esim. versomista ei ole tapahtunut lainkaan sinä aikana, kun suojavilja on ollut päällä. Suojaviljan korjuun jälkeenkin on kehitys ollut hidas, esim. versomista tapahtui syyskuun puoliväliin mennessä vain vähän. Juuret olivat suojaviljan aikana 
menneet n. $10 \mathrm{~cm}$ syvyyteen. Sen jälkeen n. kuukauden aikana lisääntyi juurten suurin syvyys vain $1-2 \mathrm{~cm}$.

Aronadan ja ni it y n u rmikan kummankin kehitys on ollut niinikään toisiaan muistuttava. Ilman suojaviljaakin oli niiden alkukehitys hyvin hidas. Aronata on näistä kahdesta ollut sittenkin hieman nopeampi. Syyskuun 5. p:nä saatu sato oli aronadalla $32 \mathrm{~g} / \mathrm{m}^{2} \mathrm{k}$.a., mutta niittynurmikasta ei saatu mitään punnittavaa. Versominen ja rönsyjen muodostuminen alkoi kummallakin jo heinäkuun alussa ja jatkui kaiken kesää. Juuret saavuttivat pian n. $10 \mathrm{~cm}$ syvyyden, mutta lisäsyvyys tuli hitaasti. Syyskuun puolivälissä oli aronadan juurien suurin syvyys $20 \mathrm{~cm}$ ja niittynurmikan $15 \mathrm{~cm}$.

Suojaviljan alla on sekä aronadan että niittynurmikan kehitys ollut aivan vähäistä. Huomiota herättää, että taimissa kuitenkin, niiden pienuudesta huolimatta on rönsyn alkuja jo suojaviljan leikkuun aikoihin. Maanpäällisten osien kehitys oli suojaviljan korjuun jälkeenkin hidas, mutta pientä versomista kuitenkin ilmeni. Juurten suurin syvyys oli kummallakin suojaviljan leikkuun aikoihin $6-7 \mathrm{~cm}$, ja se lisääntyi syyskuun puoliväliin mennessä senverran, että oli aronadalla $10 \mathrm{~cm}$ ja niittynurmikalla $8 \mathrm{~cm}$. Huomiota herättää, että primäärinen juuristo säilyi suojaviljan alla kasvaneilla taimilla kunnossa paljon pitempään kuin ilman suojaviljaa kasvaneilla.

Havaintojen yleistarkastelussa kiintyy huomio erityisesti siihen, että kaikkien kokeessa olleiden nurmikasvien kehitys on kärsinyt tavattomasti suojaviljasta.

\section{KIRJALLISUUTTA.}

(1) KokKonen, P. 1931. Roots and root systems of cocksfoot (Dactylis glomerata). Maat. Aikak. 3, p. $33-37$.

(2) Könekamp, A. 1934. Beitrag zur Kenntniss des Wurzelwachstums einiger Klee- und Gräserarten. Landw. Jahrb. 80 , p. $571-589+1$ taulu.

(3) Osvald, H. 1919. Untersuchungen über die Einwirkung des Grundwasserstands auf die Bewurzelung von Wiesenpflanzen auf Moorböden. Fühlings Landw. Zeitung 68, p. 321-340 ja $370-386$.

(4) Pohjakallio, O. 1941. Nurmen perustamistavan ja nurmikasvien kuivuudenkestävyyden vaikutuksesta niittonurmien tiheyteen ja sadon määrään. Valt. koet. julk. N:o 114.

(5) Salonen, M. 1949. Tutkimuksia viljelyskasvien juurten sijainnista Suomen maalajeissa. Acta Agr. Fenn. 70, 1.

(6) —- 1950. Viljelyskasvien aiheuttamasta varjostuksesta. Maatalous 44, p. $287-289$.

(7) Weaver, J. E. 1926. Root development of field crops. New York.

(8) Witte, K. 1929. Beitrag zu den Grundlagen des Grasbaus. Landw. Jahrb. 69, p. $263-310+4$ taulukkoa. 
S U M M A R Y:

\title{
SOME OBSERVATIONS ON THE DEVELOPMENT OF THE COMMONEST LEY PLANTS DURING THEIR FIRST SUMMER.
}

\author{
Martti Salonen \\ Institute of Crop Husbandry, University of Helsinki.
}

The main part of grasslands in Finland are leys which are maintained 2 to 4 years. This is the rule, especially with regard to grasslands for hay, and during the last few years there has been a tendency to use pastures in a similar way. For these reasons it is necessary to sow about 300000 hectares of new grasslands per year in the country. In Finland drought is very common in spring and summer, and it often delays or prevents the germination of seeds and hampers the development of small seedlings. Failures at the establishment of new leys are mostly due to drought.

In order to establish succesful leys, the development of the seedlings of ley plants, above all the development of their underground parts, roots, must be known. And the most important thing is to know the very first development of the plants. In order to throw some light upon these problems, some observations were made concerning the very first development of the most important ley plants.

In order to obtain suitable material for observations, various grasses and clovers were sown on the University farm, Viikki, in a suburb of Helsinki, in the spring of 1950. All plants employed at the test were sown separately, as stands of single crops. There were plots with nurse crop (barley Tammi) as usual, as well as plots without any nurse crop.

During the summer 1950 regular observations were made on the development of the aboveground and especially the underground parts of the different plants. For the plants growing without any nurse crop, the dates of observation were towards the end of June, at the beginning and the end of July, towards the middle of August and towards the middle of September. For plants growing under a nurse crop, observations were not made until after the harvesting of the nurse crop (Aug. 11th), viz. towards the middle of August and towards the middle of September. The technique employed at the observation of the underground parts was that developed by the writer of this paper and employed by him in an earlier investigation (5).

\section{Main results of the investigation.}

Plants growing without nurse crop. The development of the aboveground parts is most clearly shown by yields (as oven-dry material) obtained at harvesting, September 5-th. They were:

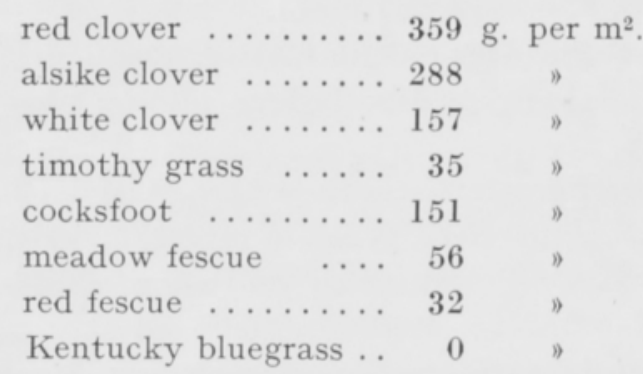

Species of clover and cocksfoot produced yields corresponding to a fair yield of hay, but the others produced very little, and Kentucky bluegrass nothing whatever to be harvested.

As to the underground parts, roots, the following facts can be stated: All species of clover were similar with regard to the development of the roots. The roots of red clover developed most quickly. Already by the beginning of July the depth of the roots was $35 \mathrm{~cm}$. for red clover, $25 \mathrm{~cm}$. for alsike clover, and $15 \mathrm{~cm}$. for white clover. Even after that the depth of the roots increased rapidly. By the middle of September the maximum depth of roots was $105 \mathrm{~cm}$. for red clover, $95 \mathrm{~cm}$. for alsike clover, 
and $105 \mathrm{~cm}$. for white clover. Thus the roots of all the investigated species of clover reached a considerable depth already during the first growing season.

The development of timothy grass was very slow at the beginning. By the beginning of July the roots had only reached a depth of 6 to $7 \mathrm{~cm}$. And even after that the development of the roots was continuously slow, e.g. the number of roots increased slowly. By the middle of September the roots had reached a depth of $18 \mathrm{~cm}$.

With cocksfoot and meadow fescue, the development of the roots was similar. In a short time the roots of both plants reached a depth of about $10 \mathrm{~cm}$. Already in July the number of roots was considerable, but they mostly grew laterally, so that the increase in depth was slight. By the middle of September the maximum depth of the roots was $23 \mathrm{~cm}$. for cocksfoot and $18 \mathrm{~cm}$. for meadow fescue.

With red fescue and Kentucky bluegrass, the root development was also similar. Of all the investigated plants, their root development proved the most slow. As late as the end of July the maximum depth of the roots was only about $10 \mathrm{~cm}$. By the middle of September the maximum root depth was $20 \mathrm{~cm}$. for red fescue and $15 \mathrm{~cm}$. for bluegrass.

Plants grown under a nurse crop. On August 11th when the nurse crop was harvested, the aboveground parts of all investigated plants were very little developed. The seedlings evidently suffered badly from drought, whereas the plants growing without a nurse crop did not seem to suffer from it. Some rains occurred at the end of August, but even after the rainfall the seedlings developing under a nurse crop recovered very slowly. At the beginning of September there was nothing to be harvested on the whole area.

The underground parts were also very little developed by the middle of August. Only clovers had reached the maximum root depth of over $10 \mathrm{~cm}$., with cocksfoot and meadow fescue it was about $10 \mathrm{~cm}$., with timothy grass, red fescue, and bluegrass it was considerably less than $10 \mathrm{~cm}$. By the middle of September red clover had reached a depth of $30 \mathrm{~cm}$., alsike clover $25 \mathrm{~cm}$., and white clover $20 \mathrm{~cm}$. Timothy grass only reached a depth of $10 \mathrm{~cm}$., cocksfoot $11 \mathrm{~cm}$., meadow fescue $12 \mathrm{~cm}$., ved fescue $10 \mathrm{~cm}$., and bluegrass only $8 \mathrm{~cm}$. With grasses growing under a nurse crop, primary roots retained a good condition much longer than with grasses growing without any nurse crop.

The most interesting thing about these observations is the extremely harmful influence exerted on all ley plant seedlings by the nurse crop. 